\title{
The Burundi Audiovisual Media Part in the Promotion of the Agricultural Sector in Burundi: "The Case of Radio"
}

\author{
Shabani Senyange \\ Communication and Social Transformation, University of Gaziantep, Turkey
}

\begin{abstract}
In this article, the aim was to analyze the role of audiovisual media in the promotion of the agricultural sector in Burundi since 2015. In so far as it is noticed overnight the birth of several media in the audiovisual sector on one hand and the agricultural sector which is considered like mother sector ensuring the survival of almost the Burundi population on the other hand. More attention will be paid to radio as a tool (medium) of education, sensitization, development and promotion.
\end{abstract}

Keywords: Media, Audiovisual, Promotion, Agricultural Sector, Radio, Burundi

DOI: $10.7176 / \mathrm{NMMC} / 77-06$

\section{Introduction}

Commonly called the heart of Africa by its shape and geographical location, Burundi is a largely mountainous country, landlocked between Central Africa and East Africa with an estimated population of about 11,216,450 million spread over an area of $27834 \mathrm{~km}^{2}$ according to the World Population Review carried out in 2018 . However, Burundi is very vulnerable to the effects of climate change because of the small size and mismanagement of its farms which, combined with extreme weather conditions, leads rapidly to a decline in agricultural production and often to an increase in food prices. Characterized by a hilly landscape, the country is often victim of extreme erosion of agricultural land that carries fertile topsoil during the rainy season. Apart from its smaller area, "the country has $2,500 \mathrm{~km}^{2}$ of lakes and $23,500 \mathrm{~km}^{2}$ of potentially agricultural land and more than $90 \%$ of rural families of which $51 \%$ are women " according to the report of the Ministry of Agriculture and Rural Development organized in 2014. Integrated in the East African community (EAC) since 2007, the country records a weak economic growth since 2015 compared to other countries members of the community due to a political instability. In addition, the country is under strong demographic pressure driven by the policy of free maternity proclaimed in 2005 just after the election of the second democratically elected president PIERRE NKURUNZIZA. Today the question is asked about the sustainability of the agricultural sector.

In Burundi, as in other countries of the Great Lakes region, which is part of this small country, radio remains the most influential medium with more audience compared to other communication media because it is used by all and on all the living standards of the country. With its unique particularity of sound, the radio seems like the only special and faithful companion who can accompany you in all your activities without preventing or disturbing you in the continuity of your activities. From this, radio can accompany you home, at work, in your beautiful car, in the streets of your neighborhood in the fields, etc.

All this shows how often this support has gained the trust of its user. As Bubacar Siné confirms "Radio has made a relatively long-lasting appearance in the daily life of Africans, probably the most popular medium and the most popular from the point of view of its audacity" ${ }^{1}$ Since the advent of mobile phones, radio has increased more and more audience everywhere even in the most remote campaigns

However, to the extent that media such as the press and television are perceived as the class media of the alphabetized people and the middle class, radio is considered as the medium of mass par excellence because any people without any distinction can to appropriate. Moreover, in his remarks; the great specialist in the African media, the French André -Jean Tudesq says that "in addition, the importance of radio is also explained by the orality of African societies and the relatively low rate of literacy"2

In this article we will try to show the state of current location of the audiovisual media registered by the National Communication Council (CNC) and their area of work since 2015 especially after the famous failed military coup d'état on the $13 / 05 / 2015$ or there has been disruption in the Burundian media landscape. It will also be a question of speaking generally about the state of the agricultural sector, since this sector is considered as the backbone of the country's economy. In this document too, we will of course demonstrate the importance of audiovisual media in promoting this sector. This taking into account the possible obstacles faced by media operators.

\subsection{Research questions}

The research seeks to answer the following primary questions.

\footnotetext{
${ }^{1}$ SINE, B., Impérialisme et théories sociologiques du développement, Paris, Editions Anthropos-IDEP, 1975, p.186

2 TUDESQ, A.-J., La radio en Afrique noire, Paris, Editions A. Pedone, 1983, p.91
} 
1. To measure the impact of Audiovisual Medias in the Burundian agricultural sector?

2. Does radio a perfect tool of communication in Burundi for the promotion of agricultural sector?

3. What strategies can be taken by audiovisual Medias sector to increase farmer's education?

4. What can be recommended to sustain and increase agricultural productivity in Burundi?

\subsection{Objectives of the study}

The main objectives of the study are as following.

1. To check role of audiovisual media on agricultural actors in Burundi.

2. To measure the place of the radio in promoting the farming sector in Burundi.

3. To measure the deep implication of community radio in rural areas.

4. Recommend main strategies and actions that must be taken to sustain and increase agricultural productivity to prevent food insecurity in Burundi.

\subsection{Signification and scope of the study}

Considering and determining the significance of communication for development( audiovisual media) on socioeconomic life and sustainable development of Burundi, this article will aid in informing audiovisual actors and policymakers on effective policies, given agricultural situation, which can be implemented to pursue an agricultural development pathway which is both progressive and sustainable. Audiovisual sector needs to be constantly reviewed against sustainable development for the country to enjoy prosperity that is evenly distributed. Although audiovisual sector been an interested socio-economic domain for Burundi, it has not been receiving significant attention in the form of heavy investments, to help in achieving a sustainable agriculture sector in Burundi.

This research is confined to Burundi and the period ranging from 2015 to 2017 evaluating annuals reports data on audiovisual media and agricultural development.

\section{Literature review}

Success of most development programs in many African countries run by government depends on the nature and extent mass media in mobilizing people for development. A developing socio-economic status, literacy and consumer spending power contributed to an expanding consumer base of multiple forms of mass media like newspapers, radio, and television. With a major objective to evaluate the comparative analysis of media reach and its effectiveness in rural areas. In this perspective, Okwu, O., Kuku, A.A., and Aba, J.L. (2007) an assessment of use of radio in agricultural information dissemination in Nigeria case. Radio has found to be the most appropriate medium of mass communication in the rural population (Okwu et al. 2007)

Toepista (2014), in his study: the impact of radio to agricultural programs on small scale farmers : the case of "Mali shambani" program on Kbc radio taifa; the result founded indicate that agricultural knowledge is essential for increased productivity and that radio is the preferred medium for small scale farmers and extension expert in sharing information on agriculture innovations. According to him radio agriculture programs alone cannot bring about change in the farming communities, there is need to integrate participatory models to serve rural farming communities effectively. Through "Mali shambani" a radio agricultural program broadcasting on $\mathrm{Kbc}$ radio taifa, the study assess responding to farmer's information needs. At the same time, the study provides an insight into best approaches to agricultural programming for radio stations and stakeholders in the agriculture sector. Furthermore, according to this research, radio remains the most cost effective means of building awareness, and supporting the adoption of new farming practices by small scale farmers.

Communication for development Round table report (UNCDR), 2010), came out to support the argumentations of Teopista (2014) that radio still remains the most widely available and affordable mass media for disadvantaged groups in the rural areas as it is often the only available. It is further indicated in the report that in some areas it is the only source of information about the weather focusing, market prices and agricultural innovations. It is further indicated in the report that in some rural areas it is the only source of information about the weather, market prices and agricultural innovations.

According to Chapman (2003), rural radio can be used to improve the sharing of information by remote rural farming communities. For him, participatory communication techniques can support agricultural extension efforts especially using local languages and rural radio to communicate with famers directly.

Arpita (2011) stated that since regional radio is confined to a small geographical territory, it serves community; which uses same resources for livelihood. Such a community has common development issues and concerns, which are relatively localized, although connected to national and regional development objectives therefore community radio connects the hard-to-reach rural populations and serves a specific goal of community radio that national or international mass media cannot deal with.

Al-Hassan et al (2013) to evaluate the role of radio Simli towards the improvement of the livelihood of people. It was founded that the station did indeed improve people's awareness creation by tackling problems of 
the community ranging from agriculture to rural development and local governance.

In 1989, Ms. Mary Ngechu a radio lecturer from the University of Nairobi' college came with the idea of developing agricultural programs on radio in order to join small scale famers in Kenya. The results of the study were fruitful (Ngechu, 1991). The results prove that radio was the most powerful information resource in the domains of rural of Kenya where she studied. Therefore, this proves that radio, as a medium is reliable in terms of communication for development.

According to Mbindyo, (1985) development is a result of complex interaction of several factors, which cannot be accomplished without mass mobilization of the rural communities.

Moemeka (1994) affirm that the effectiveness of radio depends on how it is used and for what objective and not so much on intrinsic qualities. Since radio has a large reach and therefore can attain more people than other media, this factor makes it the strongest medium of communication and change in the society.

(Okigbo, 1995) Many development-oriented communicators have pointed that radio is the medium that can reach a wide audience even in the poorest rural settings. Use of Radio to communicate agricultural information

In poor countries, the agricultural experts are in short supply and can join just a small number of peasants, yet there may be other ways like mass media of disseminating the same information to the farmers. In 1980, before rural radio became a common phenomenon, one of the communicator for rural development McAnany $(1980$, blamed that a two way communication system often lacking completely in rural domain, could keep field personnel in touch with the organizers.

\section{The current state of audiovisual media}

According to Organic Law $\mathrm{N}^{\circ} 1 / 06$ of March 8th, 2018 revising the law $\mathrm{N}^{\circ} 1 / 03$ of January 24th, 2013 bearing missions, composition, organization and functioning of the National Council of the Communication (CNC) in abbreviation, one understands by "Media" means anybody or undertaking which makes available to the public information in the form of signs, signals, writings, images, sounds or messages of any kind and which do not have the character of a private correspondence. ${ }^{1}$

In combination with the term "media", we come to a composite phrase "audio-visual media". In fact, audiovisual media are modern means of communication and information using sounds and images. They can be as qualified as multimedia. ${ }^{2}$

After the political storm in 2015, most fields of the country's life had been affected. In this continuity, the Burundian media landscape was not been spared. Of all the media sector of Burundi, the audiovisual sector is one of the domains that have been reduced in a significant way. However some audiovisual media were closed, some professionals in the audiovisual sector were in exile, some in prison, and other media were reduced in their programming i.e. not to broadcast some of their programs by the national body responsible for regulating the media in Burundi.

According to the report of the National Media Regulatory Body in Burundi C.N.C (National Council of Communication) of $2017^{3}$ is currently classifying the audiovisual media as follows:

$>$ PUBLIC MEDIA

The public domain has so far two radio stations and one television channel.

- $\quad$ Burundi National Radio

- School Radio NDERAGAKURA

- Burundi National Television

$>$ PRIVATE MEDIA

The private sector records 19 local radios known by the C.N.C:

CCIB FM +, CULTURE, IVYIZIGIRO, ISANGANIRO, MARIYA, THE VOICE OF AFRICA, BURUNDIAN SPECIAL RADIO (RSB) HUMURIZA FM, BUJA FM, UBUTUMWA BW'AMAHORO, DESTINY FM, NTUMBERO FM, UMUCO FM, STAR FM, IJWI RY ' UMUKENYEZI, COLOMBE FM, IZERE FM, EAGLE SPORT FM, BENAA RADİO RUTANA, AGAKIZA.

- $\quad$ Local TVs (3): HERITAGE TV, SALAMA TV, REMA TV.

- International Radios (4): RADIO CHINA INTERNATIONAL, VOICE OFAMERICA, HIT RADIO, BBC

- International TV (3):TV 10 distributor, CITIZEN TV, Digital terrestrial TV Star Times

- $\quad$ Studios (2): - IJAMBO and BENEVOLENCIJA. ${ }^{4}$

Even if there has been a slight decline in the Burundian audiovisual landscape, the same report of the CNC, says

\footnotetext{
${ }^{1}$ Loi organique $\mathrm{N}^{\circ} 1 / 06$ du 08 mars 2018 portant révision la loi $\mathrm{N}^{\circ} 1 / 03$ du 24 janvier 2013 portant missions, composition, organisation et fonctionnement du Conseil National de la Communication (CNC)

${ }^{2}$ Schadrack Lutangu : Médias audiovisuels et dépravation des mœurs. Constat fait aux enfants, adolescents et adultes de Kinshasa, Université de Kinshasa RDC - 2012

${ }^{3}$ RAPPORT ANNUEL DU CONSEIL NATIONAL DE LA COMMUNICATION, EXERCICE 2017

${ }^{4}$ Ibidem
} 
that: "the Burundian media landscape, the private audiovisual sector in particular has experienced a boom in the course of $2017 " 1$. Because the private domain of audio-visual recorded 6 new stations among which five (5) radios and a single TV station

\section{Authorization to use audiovisual services}

\section{Date}

February 08, 2017 Name

February 08, 2017 Radio EU Channel E

February 08, 2017 Radio Magara Times FM

October 25, 2017

December 03, 2017

December 31, 2017 Radio Sun Network (SN News) Digital TV called "BEST ENTERTAIMENT TELEVISION (BE TV) Radio Television Buntu-ijwi ry'Impfuvyi n'Abapfakazi

(See CNC 2017 report) $^{2}$ Radio Ijwi ry'Imbabazi or Voice of Mercy

According to the table above drawn, it is obvious that the current media landscape of Burundi has progressed remarkably just after the country has just emerged from a political crisis that had considerably deteriorated the media environment in Burundi caused by the famous political crisis that has just occurred before and during the year 2015. This is stated in the same report "the Burundian media landscape has experienced a net growth during the year $2017^{\prime \prime 3}$. From this, it is important to salute the courage shown by media enthusiasts and operators to invest so quickly in this area, although until now it presents certain organizational and especially legislative gaps. ${ }^{4}$

\section{The local radio stations and their locations}

\begin{tabular}{|l|l|}
\hline RADIO'S NAMES & LOCATIONS \\
\hline Radio Nationale du Burundi & Bujumbura \\
\hline Nderagakura & Bujumbura \\
\hline Destiny FM & Bujumbura \\
\hline Buja FM & Bujumbura \\
\hline Ubutumwa bw'Amahoro & Bujumbura \\
\hline CCIB FM+ & Bujumbura \\
\hline Culture & Bujumbura \\
\hline Ivyizigiro & Bujumbura \\
\hline Agakiza & Bujumbura \\
\hline Mariya & Bujumbura \\
\hline La voix d'Afrique & Bujumbura \\
\hline Colombe FM & Bujumbura \\
\hline Ntumbero FM & Bujumbura \\
\hline Star FM & Gitega \\
\hline Umuco FM & Ngozi \\
\hline Ijwi ry'Umukenyezi & Gitega \\
\hline Izere FM & Rumonge \\
\hline Radio Speciale Burundaise (RSB)Humuriza FM & Gitega \\
\hline Eagle Sport FM & Makamba \\
\hline BENAA Radio Rutana & Rutana \\
\hline & \\
\hline
\end{tabular}

Television channels and their locations

\begin{tabular}{|l|l|}
\hline Names & Locations \\
\hline La Télévision Nationale du Burundi & Bujumbura \\
\hline HERITAGE TV & Bujumbura \\
\hline SALAMA TV & Bujumbura \\
\hline REMA TV & Bujumbura \\
\hline
\end{tabular}

Tables made by the author on Annex 1 data: Repertory of Press Organs and Organizations Working with Burundi Medias (In Activities until 31/12/2017)

\footnotetext{
${ }^{1} \mathrm{http}: / /$ cnc-burundi.bi/wp-content/uploads/2017/11/Annexe-1-et-2.pdf) Annexe 1 : REPERTOIRE DES ORGANES DE PRESSE ET DES ORGANISATIONS OEUVRANT AVEC LES MEDIAS AU BURUNDI visited: $11 / 2 / 18$

2 Ibidem

${ }^{3}$ Ibidem

${ }^{4}$ The National Council of communication's report on activities for the year 2016

${ }^{5}$ Repertory of Press Organs and Organizations Working with Burundi Medias (In Activities until 31/12/2017, Op.cit
} 


\section{State of the agricultural sector since 2015}

Located in the Great Lakes region, Burundi is one of the poorest and economically less developed countries in Africa. With more than $87 \%$ of the active population employed in the agricultural sector, contributing to more than a third of the GDP, the place of agriculture in the economy and the Burundian society makes it an essential element of any strategy to fight against poverty and structural transformation, as highlighted by Barret et al (2013)

Despite its importance, the agricultural sector presents many factors that limit its development: yields are low, processing industries almost nonexistent; extension agents are almost absent, lack of information on the agricultural sector in the Burundian media landscape. This already difficult situation is compounded by poorly defined land rights, poor access to inputs such as seeds and fertilizers, as well as credit, and inefficient administrative structures.

Since 2015, Burundi has once again plunged into a political crisis provoked by the will of President Pierre Nkurunziza to want to run for the third term. This decision was followed by violent challenges and losses in human life. Indeed, the crisis was also accompanied by an economic crisis in the country with significant devaluation and loss of purchasing power of the Burundian currency on the market. However, according to the World Food Program (WFP) in 2017,"in Burundi, agriculture is the main source of food for 66.7\% of rural households and provides an average of $71.5 \%$ of household income. ${ }^{2}$ However, when misfortune comes, it does not come alone. The European Network for Central Africa (eurAC) in its article on Agriculture and Food Security in Burundi, states that in 2016 and 2017 the agricultural sector suffered a severe crisis caused by climate change causing a serious disruption of production agricultural ${ }^{\prime 3}$. In addition, WFP reports that some agricultural areas in Burundi, such as the Congo-Nile Crest area in the Imbo Plain and Buragane region, have been affected by plant pests and have contributed food insecurity ${ }^{4}$. However, the Famine Early Warning System Network (FEWS NT) late know in its report that the agricultural season B in 2017 was characterized by the lack of rain and dryness especially in the provinces of East and North, where production has been heavily impacted. On the contrary, it pointed out that season B in 2018 was characterized by heavy rains and floods, which caused agricultural production to be dependent on or compassed by moisture-resistant crops and relatively good harvests in December. $2017 .^{5}$

From this, it can be deduced that the convergence of these factors has meant that Burundian farmers are unable to satisfy the population, although "historically Burundi has been self-sufficient in its production" this makes Burundi currently, according to the report of WFP (2017) classified in the category of countries where the food insecurity is accentuated thus provoking a malnutrition of the population in certain corners of the country $^{7}$. To overcome its food security problems, the government has even planned since 2017 to create a National Agency for the Management of Food Security Stock.

\subsection{Problems of lands, repercussion on agricultural production}

Since the first socio-political troubles experienced by Burundi, they have been accompanied by massive displacements to neighboring countries such as Tanzania and the Democratic Republic of Congo (DRC) but also within the country itself. Currently, although the Burundian government is trying to repatriate its refugees; in its 2017 report, the United Nations High Commissioner (UNHCR) reports a figure of "430,000 Burundians who have fled to Tanzania, Rwanda, Uganda and the $D R C^{\prime \prime} .{ }^{8}$ However, each time when the situation arises, there are still land problems caused by the neighbors of the people on the run, or even the producers who are looking for land that wants each time to grab land or property from their neighbors. In fact, apart from the fact that these troubles are often accompanied by losses in human life, the majority of whom are men guarantors of households; it is important to point out that Burundian agriculture is dominated by women, which explains the flight of a large workforce to neighboring countries. In addition, given the fact that land and other property problems have frequently occurred each time there is unrest, Burundian politicians in their agreements decided to create an organ that will take care of its affairs to see how to overcome or find solutions to such problems that in one way or another hamper social security and especially production and the agricultural sector in general. It is from this perspective that the National Commission of Lands and Other Goods (CNTB) was born in 2002. ${ }^{9}$

\footnotetext{
${ }^{1}$ Famine Early Warning System Network (FEWS NET), Burundi Remote Monitoring Update, April 2018

${ }^{2}$ Programme Alimentaire Mondiale (PAM) \& République du Burundi, Analyse de sécurité alimentaire en situation d'urgence au Burundi, Mars 2017

${ }^{3}$ Famine Early Warning System Network (FEWS NET), Burundi Remote Monitoring Update, April 2018

${ }^{4}$ World Food Program, op cit

${ }^{5}$ Famine Early Warning System Network (FEWS NT) op cit

${ }^{6}$ European network for central Africa eurAC, Agriculture and Food Security in Burundi: European donors must help build the population's long-term resilience and agricultural capacity

World Food Program, op cit

${ }^{8}$ HCR, Burundi Regional Refugee Response Plan, December 2017

${ }_{9}^{9}$ Emmanuel NIYOMWUNGERE, "L'adminıstration De Mission En Droit Burundais: Cas De La Commission Nationale Des Terres Et
} 
However, with this commission, quite a lot of land arrangements have been made between returnees and new land occupiers: those who are driven by a spirit of sharing have decided to settle their differences through amicable, others have had to give up the goods that did not return them for fear of a bad co-habitations with their neighbors, still others persist with the justice to recover those which return to them. In addition, the World Food Program concludes that "the uncertainty caused by population movements has also contributed to the displacement of IDPs and host populations, the most insecure groups at the level of food in Burundi» ${ }^{1}$. As a result, some of the remaining cropland remains unexploited while the lawsuits are underway (in the hands of the CNTB).

\section{The implication of audiovisual media in the promotion of the agricultural sector}

According to the summary of the activity report of the CNC of the 1st semester of the year 2018, it is clear that the media landscape in general and especially the audiovisual sector in particular have been marked by information and programs bearing on the revision of the constitution of Burundi (referendum) of 2018, thus making a forgetfulness of the other important fields of the social life of the country including the agricultural sector. This makes that this sector is often put aside by the Burundian media to the politics detriment. ${ }^{2}$

During this period, certain programs and broadcasts were developed as was the case of the "AKABİRYA" program at REMA FM, for example, to accompany the referendum process ${ }^{3}$. Actually, as in all other countries in the East African region, audiovisual media are undeniably the key to development in the region. Since 1993, with the assassination of the first democratically elected Burundian president, the audiovisual media landscape has always been occupied by themes calling Burundians to make peace, reconcile and live together. According to their programming do not find any space or even little interest to talk about national development because, as we all know, it is difficult to talk about the development and obviously of agriculture in a country where there is no peace stability.

Dominated by the audiovisual media, the media landscape of Burundi currently has more than 19 radio stations and more than 4 public and private TV channels according to the CNC report of 2017. Although they are mostly concentrated in the city of Bujumbura; in the context of Burundi, radio and television remain the communication media tools most popular and coveted by the population compared to other communication media as noted in our previous lines.

\subsection{Radio}

According to Moemeka (1994) quoted by Sheila Razoa Murumba and Hezron Mogambi all of the School of Journalism and Mass Communication at the University of Nairobi "the media, especially the radio, can only reach people and otherwise inaccessible areas, but also serve as a direct instruments of education. Radio is an agent of change where new practices are cumulating to community development an outcome of changing attitudes, beliefs and skills.",

Since 2015, just after the political troubles which were followed by a military coup failed on13 May until now, the Burundian media landscape has benefited a significant number of new media of communications. From these, there are television channels and radios, the majority of these are in the community register.

In a March 2000 survey of the Ministry of Communication on the consumption of information in Burundi, it appears that the national radio was well listened to by the whole population $(96.10 \%$ of those surveyed), but the degree of satisfaction was relatively low $(53.90 \%)$. The listeners were mainly interested in educational programs. At the same time another study done in 2013 by UNESCO estimates that $82 \%$ of households have a radio and that $57 \%$ of listeners use battery receivers. In addition, the same source reports that local radios produce content in different languages and on a wide variety of topics, such as peace and reconciliation, refugees, human rights, good governance, agriculture, health etc. ${ }^{5}$

As shown by the table of local stations and their location, it is clear that almost all Burundian radios are concentrated in the town hall of the capital Bujumbura. On the other hand, only a few are scattered in five (5) provinces in a territory that currently has 18 provinces.

Moemeka (1994) also states that "the effectiveness of radio depends on how it is used and for what purpose and not so much intrinsic qualities" ${ }^{6}$. However, since radio has a broader reach that allows it to reach more

Autres Biens (C.N.T.B.)'Bujumbura, Septembre 2010

${ }^{1}$ World Food Program, op cit

${ }^{2}$ http://cnc-burundi.bi/wp-content/uploads/2017/11/synth\%C3\%A8se-rapport-semestriel.pdf SYNTHESE DU RAPPORT D’ACTIVITES DU 1ER SEMESTRE 2018

${ }^{3}$ Ibidem

${ }^{4}$ Radio for farming? An analysis of regional Radio programs and Agricultural Productivity in Kenya) by Sheila Razoa Murumba and Hezron Mogambi

${ }^{5}$ https://fr.unesco.org/radioict/countries/burundi ...

${ }^{6}$ Radio for farming? An analysis of regional Radio programs and Agricultural Productivity in Kenya) by Sheila Razoa Murumba and Hezron Mogambi op cit 
people than other media, this factor makes it a most powerful means of communication and change in society. In its work related to communication for development, the United Nations Center for Regional Development (UNCDR), which was launched in 2010, believes in its report that radio remains the most widely available and affordable mass media for disadvantaged groups in rural areas, as it is often the only one available. It reaches a large number of isolated populations over a wider geographical area. The report also indicates that in some rural areas it is the only source of information on weather, market prices and agricultural innovations. It is also an inexpensive medium that uses simple technology and is therefore better suited to less educated people living in communities and societies more characterized by oral and folkloric.

To illustrate the impact of radio as the medium of agricultural information for farmers, Okwu, Kuku and Aba (2007) conducted a study on the use of radio as a means of disseminating agricultural information to farmers of Benue State in Nigeria. The study revealed a high level of program listening. The study also revealed that $66 \%$ of respondents had listened to agricultural programs broadcast on Benue radio and that $42 \%$ of listeners had indicated that they had listened to the radio because of the content broadcast. They indicated that the programs met their information needs on agriculture and that is why they listened to them ${ }^{1}$. This means that most people listen to radio programs because of the content offered by the stations.

On this point, let us conclude by saying that Burundi, like so many other African countries that want to develop, as confirmed by Nakabugu in 2001 quoted by Toepista Nabusoba: "In developing countries, radio is the powerful and effective means for project information and knowledge related to agriculture ${ }^{2}$ ". Thus, audiovisual sector especially radio in Burundi need to work harder on their contents in order to get the attention of their audiences and then succeed on their educational mission.

\subsubsection{The profile of national radio (RTNB)}

The national radio was created in May 1960 with the mission to inform, train and entertains by radio programs, especially those relating to the educational, cultural, political, economic and social objectives of the country ${ }^{3}$. Broadcasting on two channels; in the national language (Kirundi) for the first one and in French, Swahili and English for the second. RTNB is the only station that covers the entire national territory. That is to say that it is heard by all citizens in possession of a post receiver (radio). However, knowing the importance of the agricultural sector in the country life, it should be noted that although it is a state institution that could contribute a lot in the promotion of the agricultural sector through its power to cover the whole national expanse including the rural areas that dominate the country. On the eyes of some observers, the national radio seems not to respond effectively to the promotion of the agricultural sector which is considered as the flagship sector of the country's economy and development.

According to Okigbo 1995, many development oriented communicators have pointed that radio is a medium that can reach a wide audience even in the poorest rural settings ${ }^{4}$. With its powerful transmitters, the national radio presents a major asset for the peasant population can benefit from information and especially from the relative education of the agricultural sector. Unfortunately this support although it emits currently 24 hours / 7 days, there is still little space even the insufficiency of the time to allocate to the programs and emissions pertaining to the agricultural sector. For example, it is noticeable in this support that there is no invitation from agronomists who could always be invited to discuss or give clarifications concerning the agricultural sector. Indeed, although there is an evolution in its organization, the collection of information and the programming of the RTNB so far privileged the protocol side, while the information concerning the ordinary citizen is sometimes relegated to the second place ${ }^{5}$. From this; the national radio is always pointing fingers as accompanying much the governmental action. Some people have learned to talk only about the big farmers, for example about the fields of the president of the republic and to forget about the small farmers while they are largely feeding the population. Journalists are often content to extend the microphone to officials and little to the population especially the peasant ${ }^{6}$.

\subsubsection{The profile of private local radio in the capital}

Among their missions, the local stations are one of helping people to have information that improves their lives. For a long time, we have noticed that the majority of the local radios are very concentrated in Bujumbura. They are largely interested in more urban and more universal information such as politics, economics, education, the capital's environment, sports, entertainment games, but also a part of commercial advertising, etc.

Although the agricultural sector is at the base of the national GDP, it should be noted that with their disguised commercial tendency, the local private radio stations of the capital Bujumbura are largely

\footnotetext{
${ }^{1}$ Okwu, O., Kuku, A. A., and Aba, J. L. (2007). An assessment of use of radio in agricultural information dissemination: A case study of radio Benue in Nigeria. Afr. J. Agric. Res. 2(1): 14-18.

${ }^{2}$ TOEPISTA NABUSOBA : THE IMPACT OF RADIO AGRICULTURAL PROGRAMMES ON SMALL SCALE FARMERS: THE CASE OF “MALI SHAMBANI” PROGRAMME ON KBC RADIO TAIFA

${ }^{3}$ Eva Palmans : LES MEDIAS AUDIOVISUELS AU BURUNDI

${ }^{4}$ Okigbo, C. (1995). Media and Sustainable Development.

5 Rapport annuel 2003", Département de la Radio (RTNB), 24 novembre 2003.

${ }^{6}$ Ibidem
} 
characterized by a total absence of the agricultural aspect in their information and their broadcasts because some do not have sufficient means to cover rural areas and agricultural areas in general, other are very limited in their programming emissions, in their transmission capacity but also in their timing. Paradoxically, often these media are interested in the agricultural sector when there is the rise in food prices on the markets and to a lesser extent they speak on the agricultural sector when there are climatic hazards. This is the example of the famous Kirundo famine in $2014^{1}$ which was much mediatized and was followed by a large mobilization of aid from all the provinces and funder to rescue the affected population

\subsubsection{The profile of community radio}

According to Sheila Razoa Murumba and Hezron Mogambi (2017) "Any activity that is considered vital for rural development depends to some extent on information. In the third world, agents rare and can only reach a fraction of farmers. However, there may be other ways, such as the mass media, to spread the same message to farmers ${ }^{2 \prime}$.

In our study, the radios that enter in the register of community profile are unanimous of our concerns also because in the context of Burundi are the only ones that agree and that seem preoccupied by the community cause, citizen but especially peasant farmers in a country dominated by rural areas where are established.

The community radio in Burundi, especially the rural one, came to support and especially to diversify the programming of the RTNB and some private commercial stations which were bombarding the peasants with more urban, universal information that does not have any effective impact for their socio-economic development and their daily life in general. Currently, as underlining in our lines up, the Burundian audiovisual has 7 community radios implanted in the interior of the country. Their missions and objectives differ from each other according to their editorial line, but what unites them is to be at the service of the locality in which it is installed

According to Bruce Girard (1992), community radio is "an alternative to commercial and public radio .... Its most distinctive feature is its commitment to community participation at all levels. For example, community radio listeners are the producers, managers, directors, evaluators and even the owners of the stations. "Community radio wants to be a radio that deals with the problems of the community. It is close to the community it serves and community radio programs need to be closer to the community ${ }^{3}$. "

Speaking of community radio, we find that it has multiple definitions and names according to the authors and their ideological perceptions. Some call it "rural" others "regional". For example, according to ARMAC (World Association of Community Radio Broadcasters) "Community radio is defined as having three aspects: that of a non-profit activity controlled by the community that owns it; characterized by the participation of the community "."A community radio is characterized by its owners, its programming and the community it proposes to serve. It belongs to a non-profit organization that controls it and whose structure states that membership, management, Operations and programs are provided primarily by all members of the community, and its programming must promote access to and participation in community activities and reflects the particular needs and interests of the public for whom it is intended ${ }^{4}$."

As can be seen, there is still no single definition or description of community radio. There are several similarities between the different definitions of community radio that have been formulated. A simple sentence, easy to remember, is sometimes enough to sum them up: "the radio by the people and for the people ". This sentence highlights the essential principle for a radio to be considered as true community radio.

\subsection{Current location of community radio stations by regions}

In Burundi, community radios can be considered as regional because the power of their transmitters is often limited to a distance covering in most cases a radius of 5 to 6 provinces and therefore a "region". "A regional radio is a radio station that broadcasts in a specific geographical area and is designed to serve a particular locality ${ }^{6}$. However we will find for example the radio EAGLE SPORT, BENAA RUTANA and IZERE FM cover the southern region of Burundi. For the Nordic region there is UMUCO FM. For the center of the country we find STAR FM, Burundi Special Radio (RSB) HUMURIZA FM and IJWI RY'UMUKENYEZI. From this, we only notice that the western part of the country has not until now been endowed with a community radio if not regional. This means that farmers in this region still consume information and programs from the public radio that do not respond well to their daily concerns. To accompany their development activities and especially agricultural, this part deserves a community station because the region is agriculturally very important in the life of the country and the region in particular

\footnotetext{
${ }^{1}$ http://www.isanganiro.org/spip.php?article6787 visited: 10/14/18

${ }^{2}$ Sheila Razoa Murumba and Hezron Mogambi (2017) op cit

${ }_{3}^{3}$ Bruce Girard (1992) Understanding Community Media edited by Kevin Howley

${ }^{4}$ http://unesdoc.unesco.org/images/0012/001245/124595f.pdf visited: 10/14/18

${ }^{5}$ LIGAN Dossou Charles: Quelle stratégie pour l'aménagement du statut des langues béninoises?

${ }^{6}$ Sheila Razoa Murumba and Hezron Mogambi (2017) op cit
} 


\subsection{Role of community radio in the promotion of agriculture in rural Burundi}

Currently with the 7 community radios that are located in different parts of the country, it is felt that they have not been established to play the promotion of agriculture even if some of them try to do their best. This manifests itself first in their missions and objectives:

\begin{tabular}{|c|c|c|}
\hline Radio Named & Mission (s) / Objectives & $\begin{array}{l}\text { Days and Hours } \\
\text { of Work }\end{array}$ \\
\hline STAR FM & $\begin{array}{l}\text { Promote Agri-breeding, health, reconciliation, land conflicts and } \\
\text { children's rights } 1\end{array}$ & $\begin{array}{l}7 \text { days / } 7 \text { from } \\
05 \mathrm{~h}-23 \mathrm{~h}\end{array}$ \\
\hline UMUCO FM & $\begin{array}{l}\text { Missions: education, training and public awareness in the economic, } \\
\text { educational, cultural and public health fields. It aims to boost the tertiary } \\
\text { sector which needs to be accompanied by the media in the era of } \\
\text { globalization }\end{array}$ & $\begin{array}{l}7 \text { days / } 7 \text { from } \\
05 \mathrm{~h}-23 \mathrm{~h}\end{array}$ \\
\hline $\begin{array}{l}\text { IJWI } \\
\text { RY'UMUKE- } \\
\text { NYEZI }\end{array}$ & $\begin{array}{l}\text { Mission: Contribute to the emergence of a strong and committed } \\
\text { community for its self-development } \\
\text { Objectives: Contribute to the transformation of gender relations through } \\
\text { new information, communication and education for development } \\
\text { technologies }\end{array}$ & $\begin{array}{l}7 \text { days / } 7 \text { from } \\
12 \mathrm{~h}-21 \mathrm{~h} \\
\text { (monday-friday) } \\
07 \mathrm{~h}-21 \mathrm{~h} \\
\text { (saturday- } \\
\text { sunday) }\end{array}$ \\
\hline IZERE FM & $\begin{array}{l}\text { Primary mission: contribute to preserving the environment by using } \\
\text { renewable energies }{ }^{4}\end{array}$ & $\begin{array}{l}7 \text { days / } 7 \text { from } \\
05 \mathrm{~h}-23 \mathrm{~h}\end{array}$ \\
\hline BENAA FM & $\begin{array}{l}\text { Mission: education of the population in terms of development and } \\
\text { entertainment through emissions on agriculture and rearing, health, } \\
\text { environmental protection, sports and so on }{ }^{5} \text {. }\end{array}$ & $\begin{array}{l}7 \text { days / } 7 \text { from } \\
06 \mathrm{~h}-21 \mathrm{~h}\end{array}$ \\
\hline $\begin{array}{l}\text { (RSB) } \\
\text { HUMURIZA }\end{array}$ & $\begin{array}{l}\text { Mission: to show people, especially young people, that anything is } \\
\text { possible, "just start, enjoy, work and persevere }\end{array}$ & $\begin{array}{l}7 \text { days / } 7 \text { from } \\
06 h-22 h\end{array}$ \\
\hline $\begin{array}{l}\text { EAGLE } \\
\text { SPORT FM }\end{array}$ & $\begin{array}{l}\text { Mission: promote the sport, the development and the change of mentality } \\
\text { of the population }\end{array}$ & $\begin{array}{l}7 \text { days / } 7 \text { from } \\
05 \mathrm{~h}-23 \mathrm{~h}\end{array}$ \\
\hline
\end{tabular}

Table made by the author

5.4. Agricultural programming by community radio in Burundi

\begin{tabular}{|c|c|c|c|}
\hline Radio Named & Program(s) & $\begin{array}{l}\text { Broadcasting } \\
\text { Day(s) }\end{array}$ & $\begin{array}{l}\text { Broadcasting } \\
\text { Time(s) }\end{array}$ \\
\hline UMUCO FM & Uburimyi n'Ubworozi(farming and breeding) & $\begin{array}{l}\text { Monday- } \\
\text { Friday(repeat) }\end{array}$ & $16 \mathrm{~h} 15-16 \mathrm{~h} 45$ \\
\hline $\begin{array}{l}\text { IJWI } \\
\text { RY'UMUKENYEZI }\end{array}$ & $\begin{array}{l}\text { Turime Tworore Kijambere (farm and breed } \\
\text { modern) }\end{array}$ & Thursday & $17 \mathrm{~h} 00-17 \mathrm{~h} 30$ \\
\hline STAR FM & Ikawa y'Akanovera (better tastes coffees) & $\begin{array}{l}\text { Tuesday-Friday } \\
\text { (repeat) }\end{array}$ & $18 \mathrm{~h} 20-18 \mathrm{~h} 50$ \\
\hline IZERE FM & $\begin{array}{l}\text {-Isuka mumatongo (hoe in the fields) } \\
\text {-Ikigazi soko ry'Iterambere(palm trees source } \\
\text { of development) }\end{array}$ & $\begin{array}{l}\text {-Thursday } \\
\text { - Tuesday }\end{array}$ & $\begin{array}{l}-06 \mathrm{~h} 10-06 \mathrm{~h} 40 \\
-20 \mathrm{~h} 30-21 \mathrm{~h} 00 \\
\end{array}$ \\
\hline EAGLE SPORT FM & $\begin{array}{l}\text { Duterimbere muburimyi n'ubworozi (develop } \\
\text { ourselves in farming and breeding) }\end{array}$ & Monday & 18h-18h 30 \\
\hline RSF HUMURIZA & $\begin{array}{l}\text { Murimyi Mworozi gir'ljambo (farmers and } \\
\text { Breeders have a talk) }\end{array}$ & Saturday & $14 \mathrm{~h}^{2} 5^{\prime}-14 \mathrm{~h} 55^{\prime}$ \\
\hline BENAA FM RUTAN & $\begin{array}{l}\text { Tuyage Uburimyi n'ubworozi (let's talk } \\
\text { farming and breeding) }\end{array}$ & $\begin{array}{l}\text { Tuesday-Friday } \\
\text { (repeat) }\end{array}$ & 13h:30-14h:30 \\
\hline
\end{tabular}

Interview with the programmers of these different $\operatorname{radios}^{8}$

Although they are located in the interior of the country and are very close to the population, it is clear that in their missions, the share given to agriculture is not very precise or of concern for almost all these stations and

\footnotetext{
${ }^{1}$ http://www.agashi.org/spip.php?page=star Last visit: 10/26/18

${ }^{2}$ https://www.radiotvbuntu.org/index.php/publication/societe-et-developpement/138-radio-umuco-fm-dix-bougies-deja last visit 10/9/18.

${ }^{3} \mathrm{http}: / /$ dushirehamwe.bi/radio-riu/ visited 10/9/18

${ }^{4} \mathrm{http}$ ://www.agashi.org/spip.php?page=izere visited 10/9/18

${ }^{5} \mathrm{http}: / /$ benaarutana.bi/index.php/fr/2018-02-22-15-28-28/12-descentes-sur-les-antennes-du-rbp visited 10/9/18

${ }^{6} \mathrm{https}$ ://en.unesco.org/radioict/radios/radio-humuriza-burundi visited 10/9/18

https://burundi-agnews.org/sports-and-games/burundi-inauguration-de-la-7eme-radio-communautaire-burundaise-radio-aigle-sport-fm-amakamba/visited 10/9/18

${ }^{8}$ Interview with the programmers of these different radios
} 
some consider the agricultural sector as parallel if not juxtaposed to others. In addition, with heavy programming and diversified programming covering almost every sector of the country's life, these radios face a challenge of not focusing solely on agriculture. They find themselves talking about peace, reconciliation, health, sport, the environment ... because they are located in environments that have been victims of socio-political unrest, although all its populations ensure their survival through agriculture and which should be of paramount concern for radios. However, in general, these radios have in common the education of local populations in terms of development via their programs. Paradoxically, we find that, in general, the local radio stations, if not the community one, do not give their audience enough space (to the farmers) so that they can flourish and benefit from knowledge of agricultural modernization, for example. Some stations give spaces to their audience, but note that the producers of the program are not well ground in agricultural matter. In this perceptive, as many researchers have pointed out in their works, rural radio can be used to improve agricultural information sharing for isolated rural farming communities. With the help of broadcasts and participatory communication techniques well-developed to support agricultural extension efforts, for example, local stations use local languages (Kirundi, Swahili) to communicate directly with farmers.

Cited by Sheila Razoa Murumba and Hezron Mogambi, (Chapman, R.2003: 10) Arpita (2011) argues that since regional radio is confined to a small geographic area, it serves a community that uses common resources for its livelihood. Such a community has common development issues and concerns, which are relatively localized, although linked to national and regional development goals.

In this context, Burundian rural / community radio can be of great importance in the delivery of programs or broadcasts conveying information on better farming methods, improved seeds, timely planting, agroforestry, better methods harvesting, managing compost for manure, soil conservation, alternating cultivation techniques ,marketing (agro-business), post-harvest handling and diversification ...

Since rural radio is called "by the people and for the people", the implication of the local population must be clear for the radio to communicate more effectively. In their broadcasts or programs related to the agricultural sector, producers of these can give the opportunity especially to small farmers to interact with large farmers and other competent authorities in the sector; in particular agronomists, experts in culture via formats such as live talk shows or via a telephone line. After that, the producers can realize them taking into account the needs of the rural population to which they are supposed to serve.

However, it is quite clear that with the arguments proposed in the preceding lines that Burundian community radios can contribute enormously in the transmission to small farmers of vital information that can transform their lives and their economic activities in a positive and remarkable way.

To conclude with the role of rural radio, In 1989, a study conducted by Ms. Mary Ngechu, radio teacher of the CEES (College of Education and External Studies) of the University of Nairobi, on the development of agricultural programs radio to reach out to small-scale farmers in Kenya who had been excluded from service in the traditional extension system, found that radio was the most widely used source of information in rural Kenya. To prove that, radio as a media, is reliable in terms of communication for development. After resorting to wordof-mouth communication between neighbors concerning the different agricultural techniques, the study showed that, out of 216 respondents to the sample, none of them had ever seen an extension officer or an expert from the agricultural sector visit his farm. In the same study, interviewees also indicated that it would be important for an agricultural extension officer or expert to be present when listening to agricultural programs so that in case of clarifications and queries, he would be able to offer responses as call-cell were difficult at the time due to lack of mobile handsets.

\section{Conclusion and Recommendations}

In summary, in a poor country, mostly rural, less electrified, less literate, sometimes less stable socio-politically and largely depending on the agricultural sector like Burundi, the part of the audiovisual media constitutes an unavoidable asset in the Communication for Development. The intervention of communication media such as television and especially radio in several areas of the country's life is of paramount importance. However, after the political turmoil of 2015, the media landscape of Burundi has benefited from private and community stations that show a sense of wanting to help rural people to develop through the agricultural sector. Despite several types of concerns of local populations in which they are located, it is clear that these radios, according to their respective objectives and missions militant largely for the revitalization of the primary sector; field of unprocessed reproductive activities, including agriculture. On the other hand, television on its part, although more desired and more desired at present by the local populations, it still faces on obstacles more financial than technical Burundian media operators.

In this study, the fact is that, faced with several themes deserving radio intervention in countries with the same characteristics as Burundi, the radio is perceived as the only undeniable support of communication able to educate, train and sensitize the populations to improve the socio-economic life of their daily lives. In short, even though there are no $100 \%$ agricultural radio stations in Burundi, this one remains an agricultural promotion tool 
par excellence because it makes programs for agriculture and gives voice to small farmers to be heard on topics related to the agricultural sector.

This paper further recommends that,

In a country where there are few descents of extension workers or agronomists, the training of agricultural or environmental journalists is highly desirable for a good sharing of agricultural information well searched;

Audiovisual actors must multiply programs and broadcasts in which farmers, presenters and experts / agronomists are committed to sharing their knowledge.

Promote the exchange of information and experiences between villages to help them to improve the performance of their production systems;

Although the agricultural sector is not much modernized and industrialized in Burundi, the few production and processing companies based on agriculture, both public and private as SOSUMO (for sugar), OHP (for palm oil), COTEBU (for the Cotton), OCIBU (for the Coffee), OTB (for the Tea) ... are supposed to wake up to join the world of competition by promoting the production of their daily activities through radio spots or radio advertising;

Producers and farmers' organizations wish to be better informed and more involved in this process or the communication process concerning them;

Multiplication of agricultural topics by community radios on information that would help farmers, to better guide their agricultural activities (introduction of new varieties, crop protection) and extra-agricultural (weather information, prices of agricultural products, cropping calendars, situation of agricultural commodity markets, rational management of natural resources, processing and storage of agricultural products);

\section{Acknowledgement}

I shall forever remain grateful to the Almighty to Allah for his grace bestowed on me to be able to come to the completion of this research work. I am also very thankful to all the institutions that made available the information used in this research. This paper benefited from the comments of Muhammed L.Sanyang, Gaziantep University, Turkey.

\section{References}

SINE, B., Impérialisme et théories sociologiques du développement, Paris, Editions Anthropos-IDEP, 1975, p.186.

Tudesq, A.-J., La radio en Afrique noire, Paris, Editions A. Pedone, 1983, p.91.

Rapport général ministère de l'agriculture et de l'élevage; états généraux de l'agriculture et de l'élevage (EGAE), édition 2014

Loi organique $\mathrm{N}^{\circ} 1 / 06$ du 08 mars 2018 portant révision la loi $\mathrm{N}^{\circ} 1 / 03$ du 24 janvier 2013 ; portant missions, composition, organisation et fonctionnement du Conseil National de la Communication (CNC).

Jehova-Ile MBONITEGEKA \& Emmanuel NIYOKWIZIGIRA : "Intégration du Burundi a la communauté d'Afrique de l'est: bilan et perspectives" Moulay Ismail de Meknès, Maroc, 2015.

Schadrack Lutangu : Médias audiovisuels et dépravation des mœurs. Constat fait aux enfants, adolescents et adultes de Kinshasa, Université de Kinshasa RDC - 2012.

Rapport annuel du Conseil National de la Communication, Exercice 2017.

Annexe 1 : Répertoire des Organes de Presse et des Organisations œuvrant avec Les Medias au Burundi. http://cnc-burundi.bi/wp-content/uploads/2017/11/Annexe-1-et-2.pdf

Programme Alimentaire Mondiale (PAM) \& République du Burundi, Analyse de Sécurité alimentaire en situation d'urgence au Burundi, Mars 2017.

Famine Early Warning System Network (FEWS NET), Burundi Remote Monitoring Update, April 2018.

Beuret, J-E, Fino, D, Aide au développement et conflit armé au Burundi : Pourquoi Rester, Comment Agir?, Karthala, Geneva, 2009.

HCR, Burundi Regional Refugee Response Plan, Décembre 2017.

Gouvernement du Burundi, Communiqué de Presse de la Réunion du Conseil des Ministres du Mercredi 07 et Jeudi 08 Février 2018, Février 2018.

Emmanuel NIYOMWUNGERE, "L'adminıstration de Mission en Droit Burundais: Cas de la Commission Nationale Des Terres et autres Biens (C.N.T.B.)" Bujumbura, Septembre 2010.

Sheila Razoa Murumba and Hezron Mogambi (2012) Radio for farming? An analysis of regional Radio programs and Agricultural Productivity in Kenya, University of Nairobi

Okigbo, C. 1995. Media and Sustainable Development. In Okigbo, C. (Ed.) Media and Sustainable Development (5-19). Nairobi; Media Congres

Rapport annuel 2003 : Département de la Radio (RTNB), 24 novembre 2003.

Toepista Nabusoba (2012), The Impact of radio agricultural programs on small scale farmers: The Case of "Mali Shambani” program on Kbc Radio Taifa. 
Bruce Girard (1992) Understanding Community Media edited by Kevin Howley.

Okwu, O., Kuku, A. A., and Aba, J. L. (2007). An assessment of use of radio in agricultural information dissemination: A case study of radio Benue in Nigeria. Afr. J. Agric. Res. 2(1): 14-18.

LIGAN Dossou Charles: Quelle stratégie pour l'aménagement du statut des langues béninoises?

Hubert SEREMBA SHUHURU, Presse et organe de régulation au Burundi: Contribution à une analyse critique de la relation entre la radio publique africaine et le CNC. Bujumbura, Université du Lac Tanganyika 2010 